\title{
Seasonal variation in nitrogen isotopic composition of bog plant litter during 3 years of field decomposition
}

\author{
Luca Bragazza • Paola Iacumin • Chiara Siffi • \\ Renato Gerdol
}

Received: 2 December 2009 /Revised: 2 July 2010 / Accepted: 2 July 2010 /Published online: 17 July 2010

(C) Springer-Verlag 2010

\begin{abstract}
In this study, we describe the seasonal variation in ${ }^{15} \mathrm{~N}$ abundance in the litter of two Sphagnum species and four vascular plant species during 3 years of field decomposition in an Italian Alpine bog. Litter bags were periodically retrieved at the end of summer and winter periods, and the $\delta^{15} \mathrm{~N}$ in residual litter was related to mass loss, litter chemistry, and climatic conditions. In Sphagnum litter, higher rates of decomposition during summer months were associated with an increase of $\delta^{15} \mathrm{~N}$ probably due to the incorporation of microbial organic compounds rich in ${ }^{15} \mathrm{~N}$. The litter of Eriophorum vaginatum and Carex rostrata was characterized by a decrease of $\delta^{15} \mathrm{~N}$, so that the final signature was significantly lower than in initial litter. On the other hand, the residual litter of Potentilla erecta and Calluna vulgaris was characterized by a final $\delta^{15} \mathrm{~N}$ higher than in initial litter. Our data reported a
\end{abstract}

L. Bragazza $(\bowtie) \cdot$ C. Siffi $\cdot$ R. Gerdol

Department of Biology and Evolution, University of Ferrara,

Corso Ercole I d'Este 32,

44100 Ferrara, Italy

e-mail: luca.bragazza@unife.it

\section{Bragazza}

WSL Swiss Federal Institute for Forest,

Snow and Landscape Research,

Site Lausanne, station 2,

CH-1015 Lausanne, Switzerland

\section{Bragazza}

Ecole Polytechnique Fédérale de Lausanne (EPFL), Laboratory of Ecological Systems-ECOS,

station 2,

CH-1015 Lausanne, Switzerland

P. Iacumin

Department of Earth Sciences, University of Parma,

V.le G.P. Usberti 157/A, Campus Universitario,

43100 Parma, Italy seasonality of ${ }^{15} \mathrm{~N}$ abundance in the residual litter of Sphagnum species, but not in that of vascular plant species, thus highlighting the role of differences in litter chemistry.

Keywords $\delta^{15} \mathrm{~N} \cdot$ Decomposition $\cdot$ Italian Alps $\cdot$ Litter C/N quotient $\cdot$ Peatland $\cdot$ Sphagnum $\cdot$ Vascular plants

\section{Introduction}

On a global scale, the natural abundance of nitrogen $(\mathrm{N})$ stable isotope ratio $\left(\delta^{15} \mathrm{~N}\right)$ in leaves and bulk soil is known to increase with increasing mean annual temperature and to decrease with increasing mean annual precipitation (Amundson et al. 2003; Craine et al. 2009). In addition, Craine et al. (2009) have shown that mycorrhizal plant species have a lower foliar ${ }^{15} \mathrm{~N}$ abundance than nomycorrhizal species and the largest depletion was observed for ericoid mycorrhizal symbiosis. Consequently, on a local scale, the dependence of foliar $\delta^{15} \mathrm{~N}$ on mycorrhizal association can significantly affect the ${ }^{15} \mathrm{~N}$ abundance of initial plant litter accumulating on soil.

Many processes can alter the ${ }^{15} \mathrm{~N} /{ }^{14} \mathrm{~N}$ ratio of the source and the sink pool, but usually ${ }^{15} \mathrm{~N}$ abundance increases with soil depth (Hogberg 1997). Among the $\mathrm{N}$ processes affecting $\delta^{15} \mathrm{~N}$ there are (1) ammonia volatilization, which discriminates against ${ }^{15} \mathrm{~N}$ and enriches residual soil $\mathrm{N}$ in ${ }^{15} \mathrm{~N}$; (2) nitrification from $\mathrm{NH}_{4}{ }^{+}$to $\mathrm{NO}_{3}{ }^{-}$produces $\mathrm{NO}_{3}{ }^{-}$ with a lower $\delta^{15} \mathrm{~N}$ and thus enriches the residual $\mathrm{NH}_{4}{ }^{+}$in ${ }^{15} \mathrm{~N}$; (3) denitrification, which releases $\mathrm{N}_{2}$ depleted in ${ }^{15} \mathrm{~N}$, enriches the remaining $\mathrm{NO}_{3}{ }^{-}$in ${ }^{15} \mathrm{~N}$; (4) mycorrhizal fungi are enriched in ${ }^{15} \mathrm{~N}$ so that the host plants can receive ${ }^{15} \mathrm{~N}$ depleted N compounds; (5) the mixing of soil layers by biotic and abiotic processes can affect the ${ }^{15} \mathrm{~N} /{ }^{14} \mathrm{~N}$ ratio (Hobbie and Ouimette 2009). 
In peatlands, a general increase of ${ }^{15} \mathrm{~N}$ abundance with peat depth has also been reported (Kohzu et al. 2003; Asada et al. 2005a; Cortizas et al. 2007) and attributed to microbial alteration of organic matter more than to accumulation of recalcitrant compounds (Kramer et al. 2003). However, a better understanding of the changes in ${ }^{15} \mathrm{~N}$ abundance in peat requires to know the changes in isotopic composition of fresh plant litter during early stages of decomposition, i.e., before plant remnants turn into peat because litter decomposition is a crucial process in controlling the rate of peat accumulation in peatlands (Bragazza et al. 2009). For example, Asada et al. (2005b) reported an increase of ${ }^{15} \mathrm{~N}$ abundance in the litter of the peat moss Sphagnum fuscum after 2 years of field decomposition as consequence of the incorporation of ${ }^{15} \mathrm{~N}$-enriched $\mathrm{N}$ from the surrounding. Such a result was in accordance with Connin et al. (2001) reporting an increase of $\delta^{15} \mathrm{~N}$ in the litter of desert plant species over a 5 -year period, but in contrast with Melillo et al. (1989) showing a decrease of $\delta^{15} \mathrm{~N}$ in pine needles over a 6-year period. Additional studies are then needed to better understand the extent of isotopic changes during shortterm litter decomposition in peatlands so as to allow the use of stable isotope ratios as a tracer of organic matter alteration and the origin of decomposed material.

This paper is part of a broad study investigating the stable isotope composition $\left({ }^{13} \mathrm{C}\right.$ and $\left.{ }^{15} \mathrm{~N}\right)$ in plant litter during field decomposition in an Alpine bog (Bragazza and Iacumin 2009). Here, we will describe the seasonal variation of ${ }^{15} \mathrm{~N}$ abundance in the litter of two Sphagnum species and four vascular plant species during 3 years of decomposition. We used litter bags and periodically monitored the ${ }^{15} \mathrm{~N}$ abundance of residual litter so as to relate the isotopic signature to mass loss, litter chemistry, and climatic conditions. We have hypothesized that seasonal microbial activity is primarily responsible for the changes of $\delta^{15} \mathrm{~N}$ in the residual plant litter.

\section{Materials and methods}

\section{Study site}

The study site (Marcesina peatland) is located on the Italian pre-Alps $\left(45^{\circ} 57^{\prime} \mathrm{N} ; 11^{\circ} 37^{\prime} \mathrm{E}\right)$, province of Vicenza, at an altitude of 1,300 ma.s.l. The Marcesina peatland has an area of about 2 ha and is prevalently fed by rain water.

Climatic data were collected from a meteorological station (Rifugio Marcesina) about $1 \mathrm{~km}$ away from the study bog. During the study period 2004-2007, the mean temperature of summer months, i.e., from the beginning of May until the end of September, was about $11.0^{\circ} \mathrm{C}$, whereas during winter months, i.e., from the beginning of October until the end of April, the mean temperature was about $-2.3^{\circ} \mathrm{C}$. Mean total precipitation during summer months was $820 \mathrm{~mm}$ and during winter months $740 \mathrm{~mm}$.

Litter bag preparation and sampling interval

The same dominant plant species previously selected for ${ }^{13} \mathrm{C}$ monitoring were considered in the present study, that is, Eriophorum vaginatum L., Carex rostrata Stokes, Calluna vulgaris (L.) Hull, Potentilla erecta (L.) Raüschel, Sphagnum fuscum (Schimp.) Klinggr., and Sphagnum magellanicum Brid. (Bragazza and Iacumin 2009).

Litter bags were prepared according to Bragazza and Iacumin (2009). Very briefly, in mid-September 2004, freshly senescent and undecomposed leaves were collected from vascular plant species, whereas the stem segment between 2 and $4 \mathrm{~cm}$ below the growing tip was used as representative of Sphagnum litter. Litter bags were made of polyethylene fabric with $0.5-\mathrm{mm}$ mesh size and contained about $1 \mathrm{~g}$ of air-dry Sphagnum litter or about $1.5 \mathrm{~g}$ of airdry vascular plant litter. For each plant species, three subsamples of litter were oven dried for $48 \mathrm{~h}$ at $40^{\circ} \mathrm{C}$ to calculate oven-dry weight of each litter bag before burial.

At the beginning of October 2004, 48 litter bags for each plant species were buried into the peat soil at about $5-\mathrm{cm}$ depth, in correspondence of the respective species habitats. Eight litter bags for each plant species were periodically sampled at the beginning of May and at the beginning of October. For simplicity, hereafter, we will call "winter period" the period from the beginning of October until the end of April and "summer period" the period from the beginning of May until the end of September. After sampling, each litter bag was cleaned from debris, dried at $40^{\circ} \mathrm{C}$ for $48 \mathrm{~h}$, and then weighted.

Mass loss, isotopic, and chemical analyses

The percentage mass loss at time $t$ and the seasonal rate of mass loss, i.e., the percentage mass loss during each single winter and summer period, were calculated according to Bragazza and Iacumin (2009). The rate of mass loss for each plant species has been reported by Bragazza and Iacumin (2009).

Total $\mathrm{N}$ and carbon $(\mathrm{C})$ concentration and ${ }^{15} \mathrm{~N}$ abundance were quantified in the residual litter with an elemental analyser (EA 1110, Carlo Erba, Milan, Italy) coupled online with an isotope ratio mass spectrometer (delta Plus XP, ThermoFinnigan, Bremen, Germany). In particular, $\mathrm{N}$ isotopic abundance is expressed as $\delta^{15} \mathrm{~N}$ and was calculated as follows:

$\left.\delta(\% o)=\left[\left(R_{\text {sample }} / R_{\text {standard }}\right)-1\right)\right] \times 1000$ 


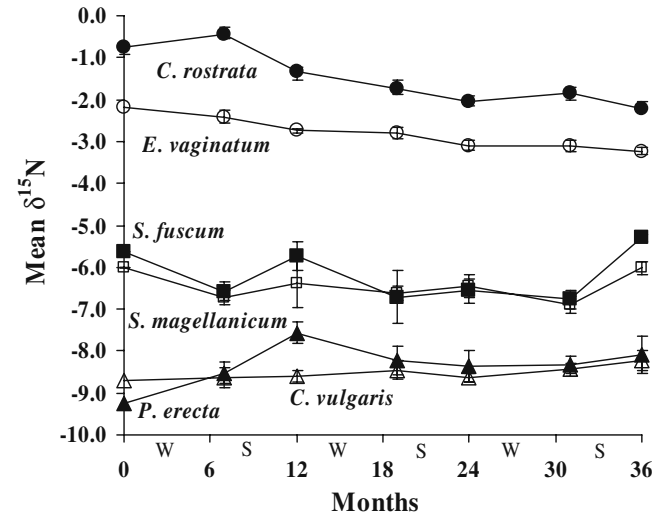

Fig. 1 Mean seasonal value $( \pm \mathrm{SD})$ of $\delta^{15} \mathrm{~N}$ in Sphagnum litter and vascular plant litter during 3 years of field decomposition. The isotopic signature at time zero corresponds to the $\delta^{15} \mathrm{~N}$ of the initial litter. $W$ is the winter period (from 1st October until the end of April), $S$ is the summer period (from 1st May until the end of September)

where $R$ is the ${ }^{15} \mathrm{~N} /{ }^{14} \mathrm{~N}$ ratio in the sample and the standard, being the latter atmospheric $\mathrm{N}_{2}$. The standard deviation of replicates was better than $0.2 \%$.

All chemical analyses were performed after grinding and sieving $(<0.1 \mathrm{~mm})$ the litter samples. All concentrations were converted to standard oven-dry weight $\left(40^{\circ} \mathrm{C}\right.$ for $\left.48 \mathrm{~h}\right)$.

The seasonal change of mean $\delta^{15} \mathrm{~N}$ was calculated as difference between the mean value at time $t$ and that at time $t-1$, i.e., $\delta^{15} \mathrm{~N}_{t}-\delta^{15} \mathrm{~N}_{t-1}$. The $\mathrm{C} / \mathrm{N}$ quotient (weight/ weight) was calculated for each litter bag basing on $\mathrm{C}$ and $\mathrm{N}$ concentration.

\section{Statistical analysis}

The effect of litter type (i.e., plant species) and time of burial on seasonal changes in $\delta^{15} \mathrm{~N}$ were tested by the twoway ANOVA, whereas the one-way ANOVA was applied to assess significant differences in litter chemistry within and among plant species. All statistical analyses were performed using Statistica for Windows v. 6.0.

\section{Results and discussion}

The $\delta^{15} \mathrm{~N}$ in initial litter differed among the selected plant species in the following sequence: Carex rostrata $>E$. vaginatum $>S$. fuscum $=S$. magellanicum $>$ Calluna vulgaris $>P$. erecta (Fig. 1). These differences can be explained taking into account the presence and the type of mycorrhizal symbiosis. Indeed, the foliar $\delta^{15} \mathrm{~N}$ in ericoid mycorrhizal and ectomycorrhizal plants is typically lower than in arbuscular mycorrhizal and nonmycorrhizal plants (Michelsen et al. 1998; Craine et al. 2009) as a consequence of a greater discrimination against ${ }^{15} \mathrm{~N}$ by ericoid mycorrhizal and ectomycorrhizal fungi (Emmerton et al. 2001). Accordingly, the low $\delta^{15} \mathrm{~N}$ in Calluna vulgaris litter reflects the presence of ericoid mycorrhizal infection, which is known to express the greatest ${ }^{15} \mathrm{~N}$ discrimination, so that the fungal mycelium is enriched and the host plant is depleted in ${ }^{15} \mathrm{~N}$ (Michelsen et al. 1998; Nordbakken et al. 2003; Aerts et al. 2009). On the other hand, the higher $\delta^{15} \mathrm{~N}$ in Carex rostrata and E. vaginatum litter is in accordance with the absence of mycorrhizal infection in these two Cyperaceae (Miller 1982; Thormann et al. 1999; Asada et al. 2005a). Rather surprisingly, P. erecta litter had the lowest ${ }^{15} \mathrm{~N}$ abundance, although this species is characterized by arbuscular mycorrhizae (Harley and Harley 1987; Titus and Leps 2000). Anyway, Craine et al. (2009) reported a great variation of foliar $\delta^{15} \mathrm{~N}$ in arbuscular mycorrhizal plants suggesting the transfer of ${ }^{15} \mathrm{~N}$-depleted $\mathrm{N}$ from the mycorrhizal fungi to the host plant in a similar way to ectomycorrhizal plants (Leigh et al. 2009). However, the extent to which the arbuscular mycorrhizal symbiosis can affect the foliar $\delta^{15} \mathrm{~N}$ of host plant is still rather unclear (Hobbie and Hobbie 2008).

The $\delta^{15} \mathrm{~N}$ of initial Sphagnum litter did not differ significantly between $S$. fuscum and $S$. magellanicum and was comparable to previous values reported for ombrotrophic Sphagnum species of the Italian Alps (Bragazza et al. 2005). Because peat mosses typically rely on atmospheric deposition as primary source of nutrients (Nordbakken et al.

Table 1 The $\mathrm{C} / \mathrm{N}$ quotient in initial litter and during the decomposition period

\begin{tabular}{lccc}
\hline & Mean initial C/N quotient & Average C/N quotient during 3years & Correlation value C/N vs. $\delta^{15} \mathrm{~N}$ \\
\hline S. fuscum & $74.5(2.9)$ & $71.8(6.7)$ & n.s. \\
S. magellanicum & $68.0(3.0)$ & $61.3(5.0)$ & n.s. \\
Carex rostrata & $42.7(4.7)$ & $29.6(4.5)$ & $0.87(P<0.01)$ \\
E. vaginatum & $38.5(1.5)$ & $21.8(3.7)$ & $0.88(P<0.01)$ \\
Calluna vulgaris & $49.2(2.3)$ & $30.8(3.7)$ & n.s. \\
P. erecta & $48.1(1.0)$ & $32.8(3.1)$ & n.s. \\
\hline
\end{tabular}

The correlation value between mean $\mathrm{C} / \mathrm{N}$ quotient and corresponding mean $\delta^{15} \mathrm{~N}$ during 3 years of field decomposition is also reported. Values are the average $( \pm \mathrm{SD})$ of five replicates for initial litter and six seasonal mean values for the average $\mathrm{C} / \mathrm{N}$ quotient. Correlation is based on Pearson's $R$ value n.s. not significant 
2003), the ${ }^{15} \mathrm{~N}$ abundance in initial Sphagnum litter seems then to reflect the $\mathrm{N}$ isotopic signature of local atmospheric deposition (Bragazza et al. 2005; Zechmeister et al. 2008).

According to the two-way ANOVA, the $\delta^{15} \mathrm{~N}$ of residual litter differed significantly among plant species and sampling periods $(P<0.01)$ with a significant interaction between plant species and time of sampling $(P<0.01)$. In the case of Sphagnum litter, mean $\delta^{15} \mathrm{~N}$ in initial and final litter did not differ significantly, but we observed that the average value of $\delta^{15} \mathrm{~N}$ in $S$. fuscum and in S. magellanicum litter at the end of summer periods $(-5.90 \pm 0.66$ and $-6.30 \pm$ 0.44 , respectively) was significantly higher $(P<0.01 ; n=24$ per species) than at the end of winter periods $(-6.69 \pm 0.42$ and $-6.75 \pm 0.35$, respectively), thus indicating an enrichment in ${ }^{15} \mathrm{~N}$ of residual litter by the increase of air temperature (Fig. 1). In addition, the mean litter $\mathrm{C} / \mathrm{N}$ quotient was negatively correlated with the mean percentage of mass loss (Pearson's $R<-0.53, P<0.05 ; n=6$ per species). We hypothesize that the relative increase of $\delta^{15} \mathrm{~N}$ during summer months could reflect a higher microbial growth and activity (Gioacchini et al. 2006), in particular the incorporation of microbial organic compounds by Sphagnum residual litter (Connin et al. 2001; Kramer et al. 2003; Asada et al. 2005a; Huygens et al. 2008). This hypothesis is supported by the fact that microbial biomass is generally enriched in ${ }^{15} \mathrm{~N}$ compared to the bulk soil (Dijkstra et al. 2006; Coyle et al. 2009). A similar mechanism has been proposed for explaining the summer enrichment of ${ }^{13} \mathrm{C}$ abundance in the same litter bags (Bragazza and Iacumin 2009). Indeed, in Sphagnum litter, the seasonal change of mean $\delta^{15} \mathrm{~N}$ was positively correlated with the corresponding seasonal change of mean $\delta^{13} \mathrm{C}$ (Pearson's $R=0.63, P=0.051$; $n=10)$.

In vascular plant litter, the average value of $\delta^{15} \mathrm{~N}$ at the end of summer periods and that at the end of winter periods did not differ significantly, thus indicating the absence of seasonal differences in the ${ }^{15} \mathrm{~N}$ abundance. The litter of Carex rostrata and E. vaginatum was characterized by a decrease of $\delta^{15} \mathrm{~N}$ so that the final ${ }^{15} \mathrm{~N}$ abundance was significantly lower $(P<0.01)$ than both values of the initial litter (Fig. 1). In addition, the mean litter $\mathrm{C} / \mathrm{N}$ quotient was positively correlated with the corresponding mean $\delta^{15} \mathrm{~N}$ (Table 1) indicating that with increasing $\mathrm{N}$ over $\mathrm{C}$ retention, the residual litter was more and more depleted in ${ }^{15} \mathrm{~N}$. We hypothesize that the decrease of ${ }^{15} \mathrm{~N}$ abundance could reflect the taxonomical diversity of decomposing microbes. Indeed, the dominance of fungi in decomposing litter is supposed to enrich the litter with microbial products having a higher $\delta^{15} \mathrm{~N}$, being fungal mycelium typically enriched in ${ }^{15} \mathrm{~N}$ (Hobbie and Colpaert 2003; Lindahl et al. 2007; Mayor et al. 2009). Instead, a dominance of bacteria can decrease the $\delta^{15} \mathrm{~N}$ of residual litter because bacteria have a greater potential for immobilizing nitrate depleted in ${ }^{15} \mathrm{~N}$ (Hogberg
1997; Lehmann et al. 2002; Myrold and Posavatz 2007). Unfortunately, we did not measure the bacteria-to-fungi biomass ratio in the residual litter, but the proposed mechanism seems to be supported by the fact that, during the study period, the lower average value of the $\mathrm{C} / \mathrm{N}$ ratio for the litter of Carex rostrata and E. vaginatum indicated nutrient conditions more suitable for bacterial than for fungal colonization (Hodge et al. 2000; Wallander et al. 2003; Hogberg et al. 2007), in particular if compared with the significantly higher average $\mathrm{C} / \mathrm{N}$ quotient $(P<0.01)$ of S. fuscum and S. magellanicum litter (Table 1).

The $\delta^{15} \mathrm{~N}$ of $P$. erecta litter showed a gradual increase during the first year of burial with a corresponding mean mass loss of $84 \% \pm 4.2 \%$, then the $\delta^{15} \mathrm{~N}$ decreased to reach a mean final value that was significantly higher $(P<0.05)$ than that of the initial litter (Fig. 1). In addition, there was a significant correlation between the mean percentage of mass loss and the corresponding mean $\delta^{15} \mathrm{~N}$ (Pearson's $R=0.83$, $P<0.05 ; n=7$, including initial value), thus supporting the hypothesis that the increase in the ${ }^{15} \mathrm{~N}$ of $P$. erecta litter could be due to microbial activity (Kramer et al. 2003; Asada et al. 2005b). A similar mechanism could also be proposed for Calluna vulgaris litter considering the positive correlation between mean percentage of mass loss and mean $\delta^{15} \mathrm{~N}$ (Pearson's $R=0.75, P=0.051 ; n=7$ including initial value), although the final ${ }^{15} \mathrm{~N}$ abundance did not differ significantly from initial value (Fig. 1). The smaller $\mathrm{N}$ isotopic changes in Calluna vulgaris litter compared to P. erecta litter were in accordance with the significantly different decomposition rate after 3 years, i.e., $69.8 \% \pm 8.1 \%$ for Calluna vulgaris and $91.8 \% \pm 1.6 \%$ for $P$. erecta. It is worthy to note that the average $\mathrm{C} / \mathrm{N}$ quotient for $P$. erecta and Calluna vulgaris litter was significantly higher $(P<0.01)$ than that of Carex rostrata and E. vaginatum litter (Table 1), thus supporting the hypothesis that decomposition was primarily driven by fungi in Calluna vulgaris and P. erecta litter.

Acknowledgements Thanks are due to I. Targa for field assistance and to R. Marchesini and F. Tressino for laboratory assistance. R. Gerdol acknowledges the funding of this study by the "Fondazione Cassa di Risparmio di Verona, Vicenza, Belluno e Ancona" through the project "R.I.T.A.", whereas L. Bragazza acknowledges the contribution by the useful discussions during the NSF-RCN (U.S.)sponsored PEATNET Workshop "Why is There Peat?" (Villanova University, March 27-28, 2008). Helpful comments and suggestions from P. Nannipieri and three anonymous reviewers are also acknowledged.

\section{References}

Aerts R, Callaghan TV, Dorrepaal E, van Logtestijn RSP, Cornelissen JHC (2009) Seasonal climate manipulations result in speciesspecific changes in leaf nutrient levels and isotopic composition in a sub-arctic bog. Funct Ecol 23:680-688 
Amundson R, Austin AT, Schuur EAG, Yoo K, Matzek V, Kendall C, Uebersax A, Brenner D, Baisden WT (2003) Globla patterns of the isotopic composition of soil and plant nitrogen. Glob Biogeochem Cycles 17:1031. doi:10.1029/2002GB001903

Asada T, Warner BG, Aravena R (2005a) Nitrogen isotope signature variability in plant species from open peatland. Aquat Bot 82:297-307

Asada T, Warner B, Aravena R (2005b) Effects of early stage of decomposition on change in carbon and nitrogen isotopes in Sphagnum litter. J Plant Interact 1:229-237

Bragazza L, Iacumin P (2009) Seasonal variation in carbon isotopic composition of bog plant litter during 3 years of field decomposition. Biol Fertil Soils 46:73-77

Bragazza L, Limpens J, Gerdol R, Grosvernier P, Hajek M, Hajek T, Hajkova P, Hansen I, Iacumin P, Kutnar L, Rydin H, Tahvanainen $\mathrm{T}$ (2005) Nitrogen concentration and $\delta^{15} \mathrm{~N}$ signature of ombrotrophic Sphagnum mosses at different $\mathrm{N}$ deposition levels in Europe. Glob Chang Biol 11:106-114

Bragazza L, Buttler A, Siegenthaler A, Mitchell EAD (2009) Plant litter decomposition and nutrient release in peatlands. In: Baird AJ, Belyea LR, Comas X, Reeve AS, Slater LD (eds) Carbon cycling in northern peatlands. Geophys Monogr Series, Volume 184, pp 99-110

Connin SL, Feng X, Virginia RA (2001) Isotopic discrimination during long-term decomposition in an arid land ecosystem. Soil Biol Biochem 33:41-51

Cortizas AM, Biester H, Mighall T, Bindler R (2007) Climate-driven enrichment of pollutants in peatlands. Biogeosciences 4:905-911

Coyle JS, Dijkstra P, Doucett RR, Schwartz E, Hart SC, Hungate BA (2009) Relationships between $\mathrm{C}$ and $\mathrm{N}$ availability, substrate age, and natural abundance ${ }^{13} \mathrm{C}$ and ${ }^{15} \mathrm{~N}$ signatures of soil microbial biomass in a semiarid climate. Soil Biol Biochem 41:1605-1611

Craine J, Elmore AJ, Aidar MPM et al (2009) Global patterns of foliar nitrogen isotopes and their relationships with climate, mycorrhizal fungi, foliar nutrient concentrations, and nitrogen availability. New Phytol 183:980-992

Dijkstra P, Ishizu A, Doucett HSC, Schwartzs E, Menyailo OV, Hungate BA (2006) ${ }^{13} \mathrm{C}$ and ${ }^{15} \mathrm{~N}$ natural abundance of the soil microbial biomass. Soil Biol Biochem 38:3257-3266

Emmerton KS, Callaghan TV, Jones HE, Leake JR, Michelsen A, Read DJ (2001) Assimilation and isotopic fractionation of nitrogen by mycorrhizal and nonmycorrhizal subarctic plants. New Phytol 151:513-524

Gioacchini P, Masia A, Canaccini F, Boldreghini P, Tonon G (2006) Isotopic discrimination during litter decomposition and the $\delta^{13} \mathrm{C}$ and $\delta^{15} \mathrm{~N}$ in soil profiles in a young artificial stand in an old floodplain forest. Isot Environ Health Stud 42:135-149

Harley JL, Harley EL (1987) A check-list of mycorrhiza in the British flora. New Phytol 105:1-102

Hobbie EA, Colpaert JV (2003) Nitrogen availability and colonization by mycorrhizal fungi correlate with nitrogen isotope patterns in plants. New Phytol 157:115-126

Hobbie EA, Hobbie JE (2008) Natural abundance of ${ }^{15} \mathrm{~N}$ in nitrogenlimited forests and tundra can estimate nitrogen cycling through mycorrhizal fungi: a review. Ecosystems 11:815-830

Hobbie EA, Ouimette AP (2009) Controls of nitrogen isotope patterns in soil profiles. Biogeochemistry 95:355-371

Hodge A, Robinson D, Fitter A (2000) Are microorganisms more effective than plants at competing for nitrogen? Trends Plant Sc 5:304-308
Hogberg P (1997) ${ }^{15} \mathrm{~N}$ natural abundance in soil-plant systems. New Phytol 137:179-203

Hogberg MN, Hogberg P, Myrold DD (2007) Is microbial community composition in boreal forest soils determined by $\mathrm{pH}, \mathrm{C}$-to-N ratio, the trees, or all three? Oecologia 150:590-601

Huygens D, Denef K, Vandeweyer R, Godoy R, Cleemput O, Boeckx P (2008) Do nitrogen isotope patterns reflect microbial colonization of soil organic matter fractions? Biol Fertil Soils 44:955964

Kohzu A, Matsui K, Yamada T, Sugimoto A, Fujita N (2003) Significance of rooting depth in mire plants: evidence from natural ${ }^{15} \mathrm{~N}$ abundance. Ecol Res 18:257-266

Kramer MG, Sollins O, Sletten R, Swart PK (2003) N isotope fractionation and measures of organic matter alteration during decomposition. Ecology 84:2021-2025

Lehmann MF, Bernasconi SM, Barbieri A, McKenzie JA (2002) Preservation of organic matter and alteration of its carbon and nitrogen isotope composition during simulated and in situ early sedimentary diagenesis. Geochim Cosmochim Acta 66:35733584

Leigh J, Hodge A, Fitter AH (2009) Arbuscular mycorrhizal fungi can transfer substantial amounts of nitrogen to their host plant from organic material. New Phytol 181:199-207

Lindahl BD, Ihrmark K, Boberg J, Trumbore SE, Hogberg P, Stenlid J, Finlay RD (2007) Spatial separation of litter decomposition and mycorrhizal nitrogen uptake in boreal forest. New Phytol 173:611-620

Mayor JR, Schuur EAG, Henkel TW (2009) Elucidating the nutritional dynamics of fungi using stable isotopes. Ecol Lett 12:171-183

Melillo JM, Aber JD, Linkins AE, Ricca A, Fry B, Nadelhoffer KJ (1989) Carbon and nitrogen dynamics along the decay continuum: plant litter to soil organic matter. Plant Soil 115:189-198

Michelsen A, Quarmby C, Sleep D, Jonasson S (1998) Vascular plant ${ }^{15} \mathrm{~N}$ abundance in heath and forest tundra ecosystems is closely correlated with presence and type of mycorrhiza in roots. Oecologia 115:406-418

Miller OK (1982) Mycorrhizae, mycorrhizal fungi and fungal biomass in subalpine tundra at Eagle summit, Alaska. Holarct Ecol 5:125134

Myrold DD, Posavatz NR (2007) Potential importance of bacteria and fungi in nitrate assimilation in soil. Soil Biol Biochem 39:17371743

Nordbakken JF, Ohlson M, Hogberg P (2003) Boreal bog plants: nitrogen sources and uptake of recently deposited nitrogen. Environ Pollut 126:191-200

Thormann MN, Currah RS, Bayley SE (1999) The mycorrhizal status of the dominant vegetation along a peatland gradient in southern boreal Alberta, Canada. Wetlands 19:438-450

Titus JH, Leps J (2000) The response of arbuscular mycorrhizae to fertilization, mowing, and removal of dominant species in a diverse oligotrophic wet meadow. Am J Bot 87:392-401

Wallander H, Nilsson LO, Hagerberg D, Rosengren U (2003) Direct estimates of $\mathrm{C}: \mathrm{N}$ ratios of ectomycorrhizal mycelia collected from Norway spruce forest soils. Soil Biol Biochem 35:997-999

Zechmeister HG, Richter A, Smidt S, Hohenwallner D, Roder I, Maringer S, Wanek W (2008) Total nitrogen content and $\delta^{15} \mathrm{~N}$ signatures in moss tissue: indicative value for nitrogen deposition patterns and source allocation on a nationwide scale. Environ Sci Technol 42:8661-8667 